\title{
The impact of ssek2 deletion on Salmonella enterica serovar typhimurium virulence in vivo and in vitro
}

\author{
Xiaojie Zhang ${ }^{1,2+}$, Lei He $\mathrm{H}^{1,2^{*}+}$, Chunjie Zhang ${ }^{1,2^{*}}$ (D) Chuan $\mathrm{Yu}^{1,2}$, Yadong Yang ${ }^{1,2}$, Yanyan Jia ${ }^{1,2}$, \\ Xiangchao Cheng ${ }^{1,2,3}$, Yinju Li ${ }^{1,2}$, Chengshui Liao ${ }^{1,2}$, Jing Li $i^{1,2}$, Zuhua Yu ${ }^{1,2}$ and Fuyu Du, ${ }^{1,2}$
}

\begin{abstract}
Background: Salmonella enterica is regarded as a major public health threat worldwide. Salmonella secretes the novel translocated effector protein K2 (SseK2), but it is unclear whether this protein plays a significant role in Salmonella enterica Typhimurium virulence.

Results: A $\triangle$ sseK2 mutant of S. Typhimurium exhibited similar growth curves, adhesion and invasive ability compared with wild-type (WT) bacteria. However, deletion of sseK2 rendered Salmonella deficient in biofilm formation and the early proliferative capacity of the $\Delta$ sseK2 mutant was significantly lower than that of the WT strain. In vivo, the $L_{50}$ (median lethal dose) of the $\Delta$ sseK2 mutant strain was increased $1.62 \times 10^{3}$-fold compared with the WT strain. In addition, vaccinating mice with the $\Delta$ sseK2 mutant protected them against challenge with a lethal dose of the WT strain. The ability of the $\Delta$ sseK2 mutant strain to induce systemic infection was highly attenuated compared with the WT strain, and the bacterial load in the animals' internal organs was lower when they were infected with the $\Delta$ sseK2 mutant strain than when they were infected with the WT strain.
\end{abstract}

Conclusions: We conclude that sseK2 is a virulence-associated gene that plays a vital role in Salmonella virulence.

Keywords: Salmonella typhimurium, $\Delta$ sseK2 mutant, Biofilm formation, Virulence

\section{Background}

Salmonella enterica is a facultative intracellular Gramnegative pathogen that has a wide range of hosts and is regarded as a major public health concern worldwide [1]. Various Salmonella and serovars still pose a critical threat to human health, especially in developing countries [2, 3]. Salmonella enterica can cause a variety of animal diseases, such as typhoid fever. Salmonella pathogenic is mainly facilitated by a type III secretory system (T3SS) encoded by the genes in Salmonella pathogenicity islands 1 and 2 (SPI-1 and SPI-2) [4, 5]. SPI-1 is mainly expressed in the intestines to mediate invasion of epithelial cells by Salmonella, while SPI-2 can facilitate intracellular proliferation of Salmonella in

\footnotetext{
* Correspondence: helei4280546@163.com; cjzhang@sina.com

${ }^{+}$Xiaojie Zhang and Lei He contributed equally to this work.

${ }^{1}$ The Key Lab of Animal Disease and Public Health, Henan University of Science and Technology, 263 Kaiyuan Avenue, Luoyang 471023, Henan, China

Full list of author information is available at the end of the article
}

the host's macrophages [6, 7]. Although sseK2 is an important gene that is located on SPI-2 [8], it is unknown whether this gene plays a role in Salmonella virulence.

The SseK proteins in $S$. Typhimurium are regarded as T3SS effectors, and include SseK2 (STM2137), SseK1 (STM4157) and SseK3 (sb26) [9]. Interestingly, these proteins are highly similar in different bacterial species, such as the enterohemorrhagic Escherichia coli and Citrobacter rodentium [10, 11]. The SseK1 and SseK2 proteins are encoded by genes located in the islands on bacterial chromosomes, and share $61 \%$ identity at the amino acid level [10]. Both SseK1 and SseK3 are found to inhibit the activation of the proinflammatory transcription factor NF-kB and work as GlcNAc ( $N$-acetylglucosamine) transferases that could modify the TNFR1-associated death domain protein TRADD [12, 13]. Notably, all of the key residues necessary for SseK3 enzyme activity are conserved in SseK2 [12]. While a previous study that deletion of the sseK1 gene can significantly reduce virulence [14],

(c) The Author(s). 2019 Open Access This article is distributed under the terms of the Creative Commons Attribution 4.0 International License (http://creativecommons.org/licenses/by/4.0/), which permits unrestricted use, distribution, and reproduction in any medium, provided you give appropriate credit to the original author(s) and the source, provide a link to the Creative Commons license, and indicate if changes were made. The Creative Commons Public Domain Dedication waiver (http://creativecommons.org/publicdomain/zero/1.0/) applies to the data made available in this article, unless otherwise stated. 
there is no evidence regarding how the presence of the sseK2 gene promotes bacterial virulence. The Salmonella protein $\mathrm{K} 2$, which is a novel translocated protein, is a secreted T3SS effector protein that is involved in bacterial translocation. In addition, the gene encoding SseK2 is highly conserved in the Salmonella genome [10]. Research has suggested that SseK2 is also an GlcNAc transferase [15], but it is uncertain whether sseK2 has an effect on $S$. Typhimurium virulence. Gaining a better understanding of the effects of $s s e K 2$ on bacterial virulence may help improve the design of live attenuated vaccines, which are regarded as an effective means of preventing Salmonella infection $[16,17]$.

In this study, we implemented a $\mathrm{SacB} /$ sucrose counterselection strategy to obtain a $\Delta s s e K 2$ mutant. The potential virulence of $\Delta s s e K 2$ mutant was examined in both in vitro and in vivo models of infection. We verified that deletion of sseK2 reduces Salmonella virulence, indicating that sseK2 is a Salmonella virulence-associated gene. Our data clearly showed that sseK2 plays a vital role in Salmonella virulence.

\section{Results}

Analysis of the $\Delta$ sseK2 mutant

An in-frame deletion of the sseK2 gene was cloned into pRE112 to create a recombinant suicide plasmid. The $\Delta$ sseK2 mutant was PCR (polymerase chain reaction)-amplified using primers sseK2 - F and sseK2 - R. We obtained an approximately 459-bp fragment (Fig. 1). The sseK2 deletion was confirmed by DNA sequencing.

\section{Growth characteristics of the $\Delta$ sseK2 mutant}

The $\Delta s s e K 2$ mutant, the WT strain, and a complemented strain were verified by antibiotic selection and PCR, and the results showed that their growth characteristics in LB (LuriaBertani) medium did not differ greatly (Fig. 2). This indicated that sseK2 deletion did not influence the growth characteristics of $S$. Typhimurium.

\section{Stability of the $\Delta$ sseK2 mutant}

The $\Delta s s e \mathrm{~K} 2$ mutant was serially passaged 60 times in LB medium, and the presence of the sseK2 deletion was then assessed by PCR (Fig. 3). The sseK2 deletion was still detectable in the $\Delta s s e K 2$ mutant strain, indicating that this strain has good genetic stability.

\section{Biofilm formation and morphology assay}

Biofilm formation is an important aspect of Salmonella virulence [18-20]. Therefore, we assessed biofilm formation in the three strains noted above. The results showed that the ability of the $\Delta s s e K 2$ mutant to form biofilm was significantly lower than that of the WT and complemented strains, based on $\mathrm{OD}_{570}$ values (Fig. 4), indicating

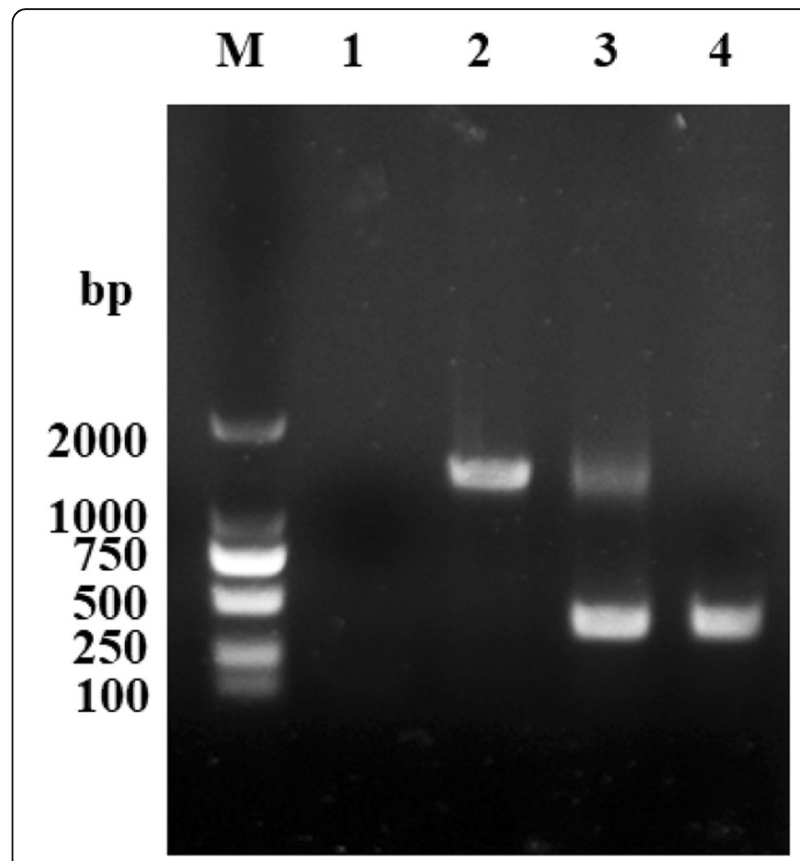

Fig. 1 Identification of the $\Delta$ sseK2 mutant by PCR (polymerase chain reaction). M: marker (DL2000); 1: negative control; 2: WT; 3: singlecrossover $\Delta$ sseK2 mutant; 4: double-crossover $\Delta$ sseK2 mutant

that sseK2 is necessary for the formation of biofilm by $S$. Typhimurium.

The $\Delta$ sseK2 mutant has altered biological activity in vitro The invasive and adhesive abilities of the sseK2 mutant and the complemented strain were similar to those of the WT strain (Table 1). This suggests that sseK2 does not play an important role in promoting $S$. Typhimurium attachment to and invasion of host macrophages. The $\Delta s s e K 2$ mutant intracellular load increased by 0.5 $\log$ over a period of $3.5 \mathrm{~h}$ (Fig. 5). In contrast, the intracellular load of the WT and complemented strains increased by 2.3 logs over the same time period. However, over a $23.5 \mathrm{~h}$ period, the number of $\Delta s s e K 2$ mutant bacteria decreased 1.9 logs, whereas the number of WT bacteria decreased by 2.8 logs. These data show that there is a significant difference in intracellular proliferation between the $\Delta s s e K 2$ mutant and the WT strain $(P<$ 0.05 ), indicating that SseK2 is required for intracellular survival of Salmonella in vitro.

The virulence characteristics of the $\Delta s s e K 2$ mutant in vivo A mouse model of infection was established to determine whether $s s e K 2$ deletion would alter the virulence characteristics of $S$. Typhimurium in vivo. The results from this experiment are shown in Fig. 6. All of the mice injected with $2.4 \times 10^{6} \mathrm{CFU}$ (colony-forming unit) of the $\triangle$ sseK2 mutant survived, while the 16.7, 50, 33.3 and $83.3 \%$ of mice injected with $2.4 \times 10^{7}, 2.4 \times 10^{8}, 1.2 \times 10^{9}$ 


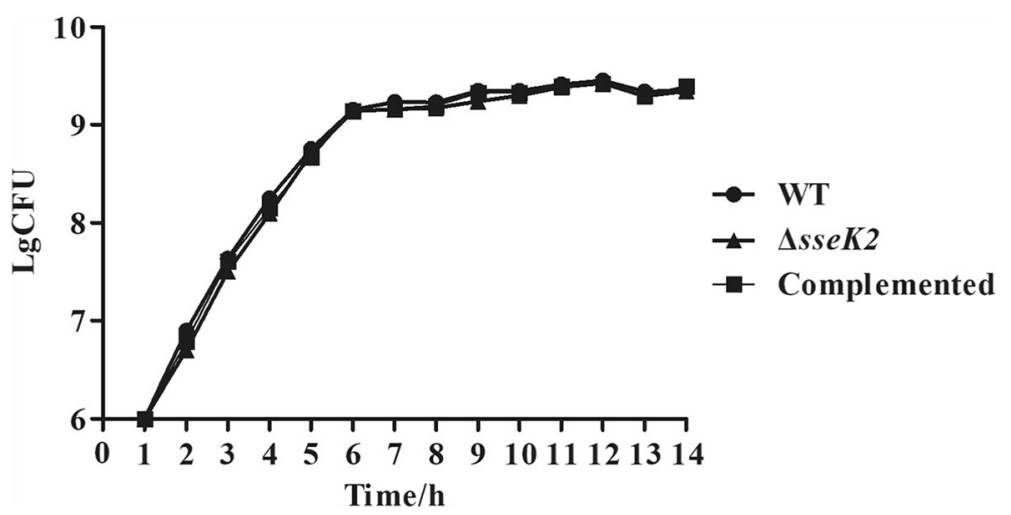

Fig. 2 Growth curves for the WT, $\Delta s s e K 2$, and complemented strains. All strains were cultured in LB medium. Growth curves were generated by determining viable cell counts

or $4.8 \times 10^{9} \mathrm{CFU}$, respectively, died (Fig. 6b). In contrast, $16.7,50 \%$ or $83.3 \%$ of mice injected with $2.25 \times 10^{6}$, $2.25 \times 10^{5}$ or $2.25 \times 10^{4} \mathrm{CFU}$, respectively, died (Fig. 6a). The $\mathrm{LD}_{50}$ values for the $\Delta s s e K 2$ mutant, the WT strain, and the complemented strain were $3.44 \times 10^{8}, 2.12 \times 10^{5}$ and $4.30 \times 10^{5} \mathrm{CFU}$, respectively. All of the mice in negative control group survived (data not shown).

The number of $\Delta s s e K 2$ or WT bacteria in the mouse livers increased to 7.75 logs and 8.35 logs, respectively, between $4 \mathrm{~h}$ and $72 \mathrm{~h}$ and then decreased to 5.06 logs and $5.48 \mathrm{logs}$, respectively, at $120 \mathrm{~h}$ post-infection. This indicates that the bacterial load of the $\Delta s s e K 2$ mutant in the liver had begun to decrease. (Fig. 7a). In the Peyer's patches (PPs), the $\Delta s s e K 2$ mutant and WT loads increased to 7.13 logs and 8.48 logs, respectively, at 4-72 $\mathrm{h}$, but decreased to $4.96 \mathrm{logs}$ and 5.17 logs, respectively, at $120 \mathrm{~h} \mathrm{(Fig.} 7 \mathrm{~b}$ ). Meanwhile, the $\Delta s s e K 2$ mutant and WT loads in the spleen increased to $7.76 \operatorname{logs}$ and 7.98

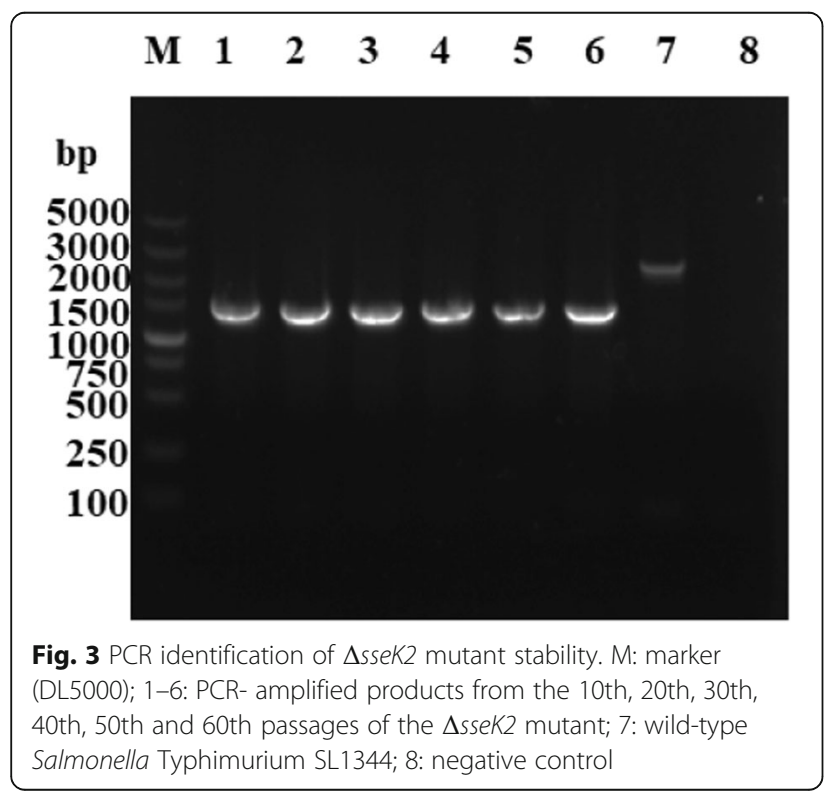

logs, respectively, between $4 \mathrm{~h}$ and $72 \mathrm{~h}$ post-infection. However, they decreased to 5.07 logs and $5.20 \operatorname{logs}$, respectively, after $120 \mathrm{~h}$ post-infection (Fig. 7c).

After $4 \mathrm{~h}$ of infection, $S$. Typhimurium could be recovered form in the liver, spleen, and PPs. At $24 \mathrm{~h}$ post-infection, there was a significant difference in the number of $\Delta s s e K 2$ mutant and WT bacteria recovered from the spleen, liver, and PPs. Moreover, in mice infected with the complemented strain, the number of bacteria was restored to the same level as in mice infected with the WT strain (Fig. 7d, e, f). The bacterial counts from in the spleen and liver were significantly lower than those from mice infected with the parental strain $24 \mathrm{~h}, 48 \mathrm{~h}$, and $72 \mathrm{~h}$ post-infection $(P<0.05)$, but the counts for the complemented strain were restored to level of the parent strain.

\section{Discussion}

The results from this study provide evidence that deletion of sseK2 can significantly reduce the virulence of Salmonella. The sseK2 deletion significantly decreased

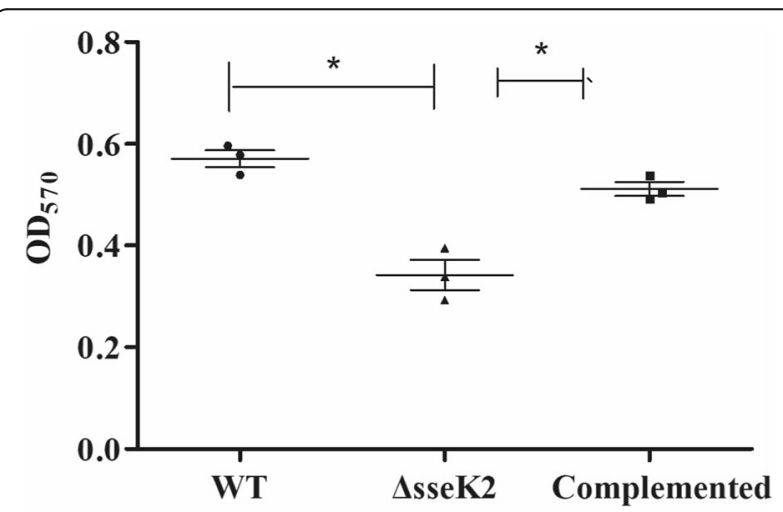

Fig. 4 Biofilm formation by the WT, $\Delta s s e K 2$, and complemented strains. The asterisk $\left(^{*}\right)$ indicates statistically significant differences between the $W T, \Delta$ sseK2 and its complemented strains $(P<0.05)$. $\mathrm{OD}_{570}$ values for the $\mathrm{WT}, \Delta$ sseK2 and complemented strains as determined by crystal violet staining 
Table 1 Role of the $\Delta s s e K 2, W T$ and complemented strains in adherence to and invasion of J774A.1 cells

\begin{tabular}{lll}
\hline Strains & $\begin{array}{l}\text { Percentage adherence } \\
\text { (no.adhered/ } \\
\text { no. inoculated) }\end{array}$ & $\begin{array}{l}\text { Percentage invasion } \\
\text { (no.invaded/no. } \\
\text { inoculated) }\end{array}$ \\
\hline$\Delta$ sseK2 & $1.63 \pm 0.16$ & $2.96 \pm 0.12$ \\
WT & $1.8 \pm 0.12$ & $3.40 \pm 0.41$ \\
Complemented & $1.75 \pm 0.13$ & $3.1 \pm 0.38$ \\
\hline
\end{tabular}

Values are mean \pm SD

biofilm formation, the proliferation in macrophages in vitro, and the bacterial load in liver and spleen decreased in vivo infection models, indicating sseK2 is a virulenceassociated gene that plays a vital role in Salmonella virulence.

SseK2 is a novel translocated $S$. Typhimurium protein that is highly conserved among Salmonella strains [10]. However, the function of SseK2 was unknown until now. Biofilm formation is required for Salmonella to spread $[21,22]$. Salmonella in biofilms are more resistant to hostile environments than individual bacteria [23, 24]. In vivo, biofilm formation helps bacteria evade the immune system and resist antibiotics-mediated killings, thereby resulting in chronic infection [23, 24]. Biofilm formation also contributes to the spread of Salmonella in vitro, because bacteria in biofilms are more resistant to disinfectants and physical stress than individual bacteria [25-27]. The biofilm matrix is mainly composed of curli fimbriae and cellulose [28]. A few proteinaceous compounds such as BapA and DksA have been reported to participate in biofilm formation [28]. We found that the ability of the $\triangle$ sseK2 mutant to form biofilms was significantly decreased compared to the WT strain, indicating that the SseK2 protein could be a novel proteinaceous compound in biofilms. Furthermore, the ability to form biofilms is an important virulence factor during Salmonella infection. A strain of Salmonella that produces biofilm was more virulent in chickens than s non- biofilm-forming strain [29]. Thus, a decreased ability to form biofilms could be involved in the decreased virulence of $\Delta s s e K 2$ mutant. However, its influence on the biofilm formation in vivo should be explored in the future.

However, we did not observe any statistically significant difference in adhesion and invasion between the $\triangle$ sseK2 mutant and the WT strain, indicating that, at least in vitro, Salmonella invasion and adhesion are not controlled by sseK2. The apparent discrepancy between the effect of $s s e K 2$ deletion on biofilm formation and its lack of effect on invasion and adhesion may be because $s s e K 2$ is located in SPI-2 [8]. A major function of SPI-2 is to enable intracellular bacterial replication, while the principal role of the SPI-1 encoded secretion system is to facilitate bacterial invasion of epithelial cells [30]. Proliferation of the $\Delta s s e K 2$ mutant in host cells was significantly reduced by $10^{-2}$-fold compared with the WT strain (Fig. 5). Thus, sseK2 is necessary for biofilm formation and intracellular proliferation in vitro, but is dispensable for host cell adhesion and invasion. Interestingly, another protein, DksA, also plays an important role in biofilm formation but is dispensable for adhesion [31].

The $\mathrm{LD}_{50}$ of the $\triangle s s e K 2$ mutant strain was markedly increased compared with the WT strain. Mice were infected with WT strain, began to die on the third day post-infection, whereas mice infected with the $\Delta s s e K 2$ strain began to die on the tenth day post-infection (Fig. 6). We further tested the $\Delta s s e K 2$ mutant and WT strains in $\mathrm{BALB} / \mathrm{c}$ mice to determine differences in bacterial burdens post-infection. Consistent with our in vitro results, the $\mathrm{LD}_{50}$ assay showed that the $\triangle s s e K 2$ mutant developed a systemic infection more closely than WT strain, indicating that $s s e K 2$ could affect the ability of $S$. Typhimurium to establish systemic infection in vivo. Salmonella invades

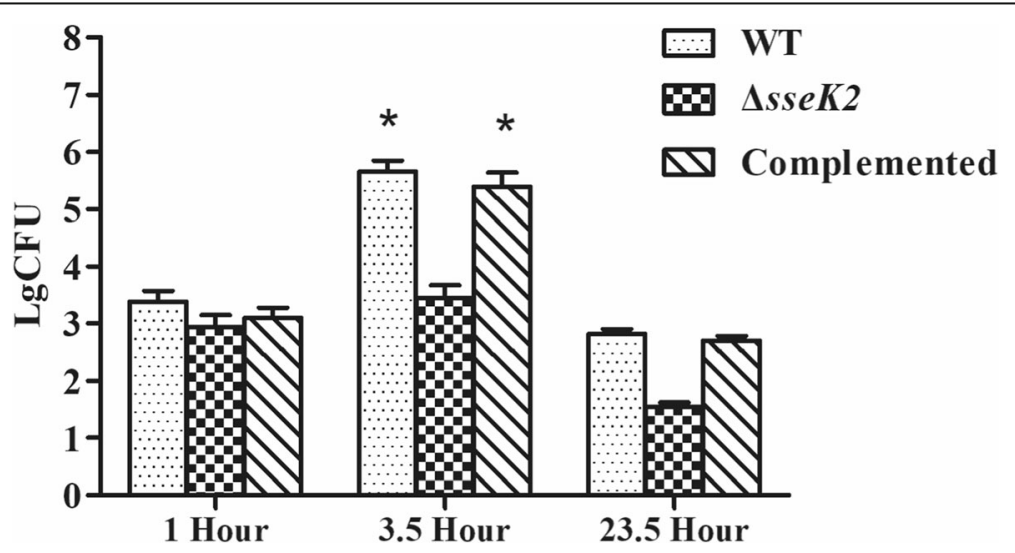

Fig. 5 Intracellular proliferation of the WT, $\Delta$ sseK2, and its complemented strains in J774A.1. cells. The WT, $\Delta$ sseK2, and complemented strains were co-incubated with J774A.1. cells, and the number of bacteria was counted at $1,3.5$ and $23.5 \mathrm{~h}$. The asterisk $\left({ }^{*}\right)$ indicates that there was a statistically significant difference between the WT, $\Delta$ ssek2 and complemented strains at $3.5 \mathrm{~h}$ compared with $1 \mathrm{~h}$. $(P<0.05)$ 
a

\section{WT}
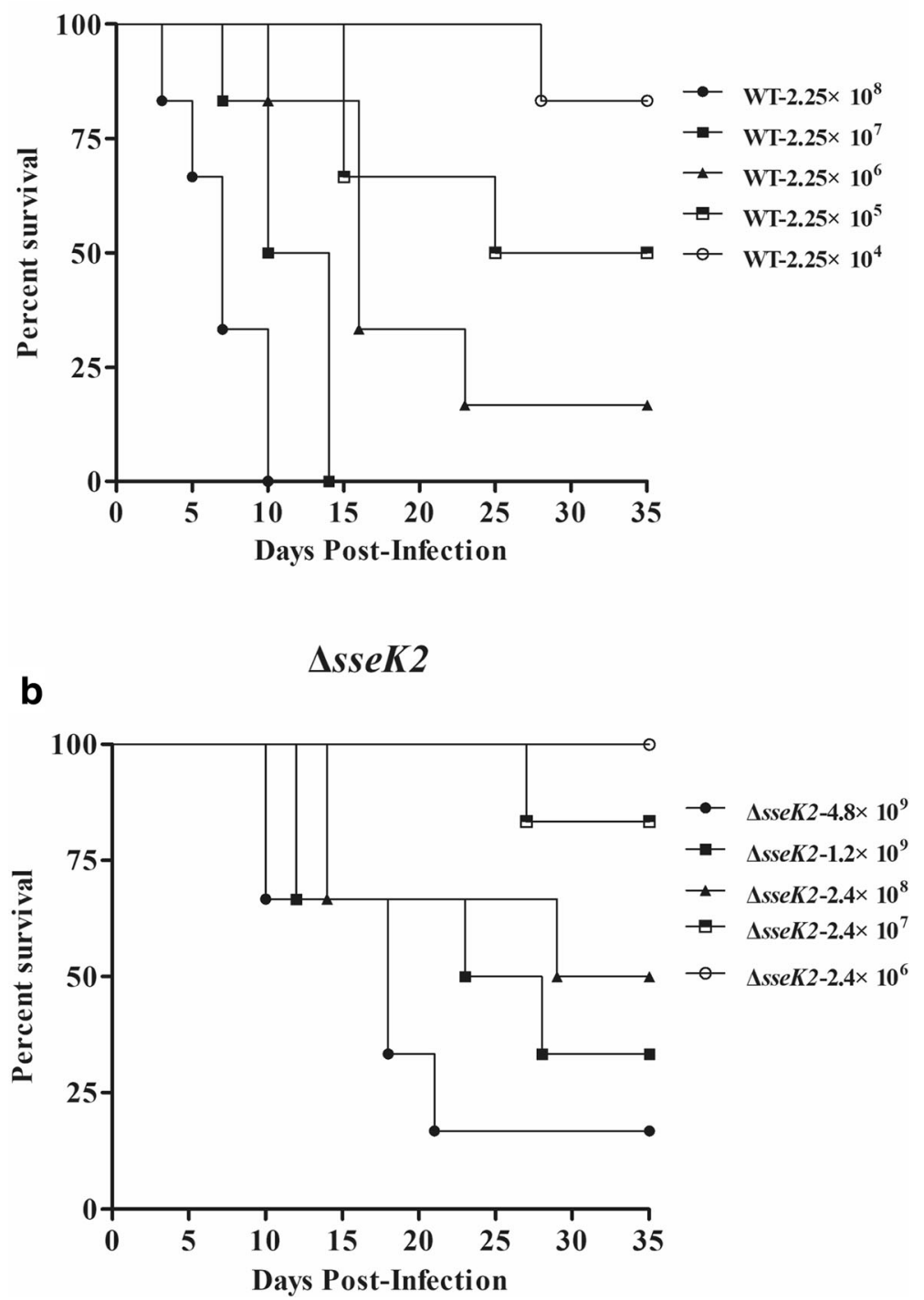

Fig. 6 Percent survival of mice infected with the WT (a) or $\Delta$ sseK2 mutant strain (b). The mice were inoculated by intraperitoneal injection, and mortality was monitored over 5 weeks

multiple organs in mice, such as the liver, spleen, and PPs. The bacterial loads of the complemented strain were similar to those of the WT strain in multiple organs, while bacterial loads of $\triangle s s e K 2$ mutant were lower than WT in multiple organs. Furthermore, the $\Delta s s e K 2$ mutant caused less tissue damage to the liver, PPs and spleen (data not shown). These data clearly show that $s s e K 2$ may be involved in facilitating bacterial infection and that sseK2 gene contributes to $S$. Typhimurium virulence.

It is crucial for live attenuated Salmonella vaccines to effectively confer protection against wild-type $S$. Typhimurium [32]. Therefore, we also evaluated the protective efficacy of the $\Delta s s e K 2$ mutant against oral challenge with SL1344. Only $62.5 \%$ mice vaccinated with the $\Delta s s e K 2$ mutant survived, whereas the control group exhibited $100 \%$ mortality (data not shown). Although the $\Delta$ sseK2 mutant does not confer enough of a protective effect to be used as a new attenuated Salmonella vaccines, deletion of the sseK2 gene and other genes could be a good way to construct a live attenuated vaccine, as deletion of two or three virulence-related genes is regarded as a good approach for designing novel attenuated Salmonella vaccine [33-35]. In addition, genetic stability and no reversion to virulent strain are necessary conditions for a vaccine candidate $[36,37]$. The $\Delta s s e K 2$ mutant grew similarly to the WT strain and had a good genetic stability over 60 passages, which will be advantageous in developing novel vaccine. 

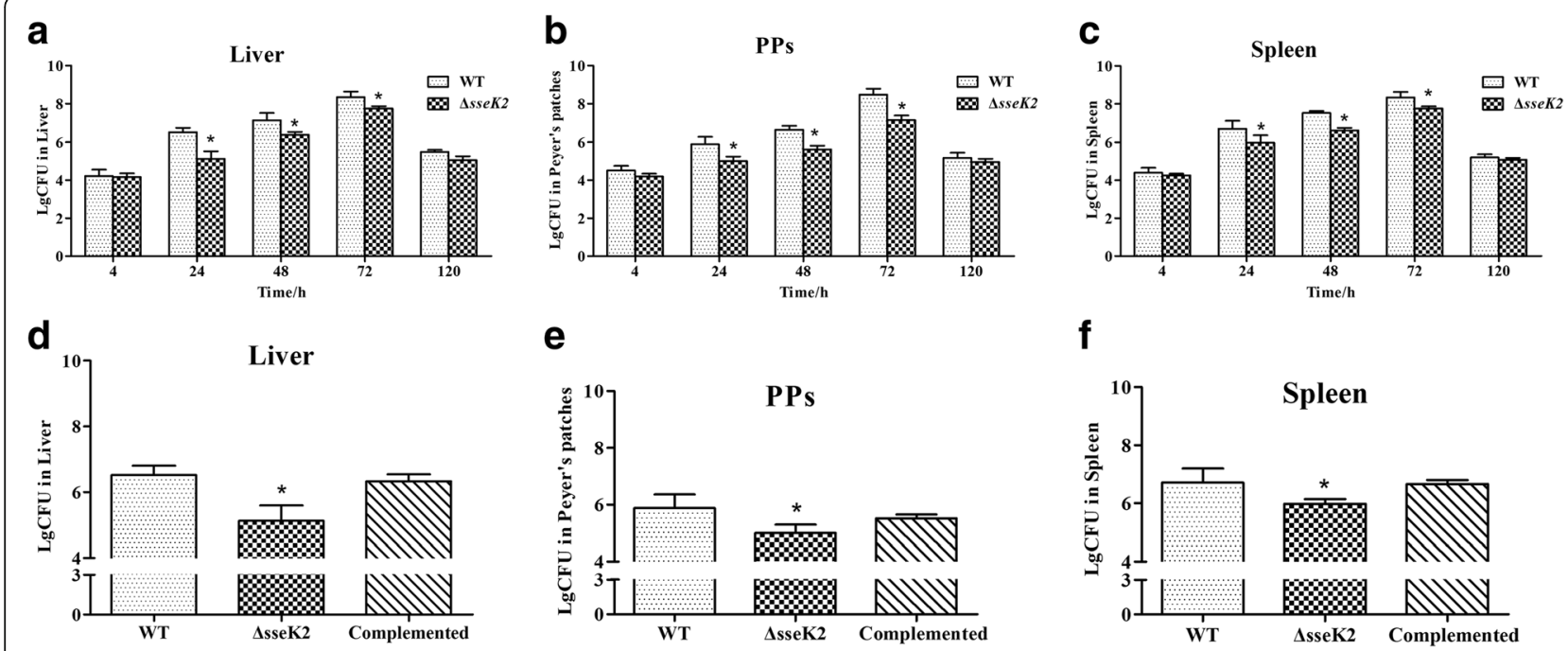

Fig. 7 Analysis of WT and $\Delta$ sseK2 mutant bacterial loads in the liver (a), PPs (b), and spleen (c) of mice. The asterisk $\left(^{*}\right)$ indicates statistically significant differences between the WT and $\Delta$ ssek2 mutant strains $(P<0.05)$. The virulence of the complemented strain was evaluated based on the bacterial load in the liver (d), PPs (e), and spleen $(\mathbf{f})$ of mice at $24 \mathrm{~h}$

\section{Conclusions}

In summary, we constructed a $\Delta s s e K 2$ mutant of $S$. Typhimurium, and found that lack of sseK2 affects $S$. Typhimurium pathogenicity by decreasing its virulence both in vitro and in vivo. This study provides a new and effective candidate for developing attenuated Salmonella vaccines.

\section{Methods}

Animals, bacterial strains, plasmids and culture conditions Specific pathogen-free (SPF) BALB/c mice (age, 5-6 weeks; body weight, $20 \pm 2 \mathrm{~g}$ ) were obtained from the experimental animal center of Henan University of Science and Technology (Luoyang, China). This study was carried out in accordance with the regulations established by the Chinese Ministry of Science and Technology. All animals were subjected to a clinical examination to assess their physical appearance and the normality of their behavior, and those presenting signs of disease were removed. The mice were anesthetized with $20 \%$ urethane (ethyl carbamate) solution by intraperitoneal injection. 5 min later, the anesthetized mice were sacrificed by cervical dislocation. Then the corresponding animal experiments were started. All animals were humanely handled. This work adheres to ARRIVE guidelines (Additional file 1). The study was approved by the Institutional Animal Care and Use Committee (IACUC) of the College of Animal Science and Technology, Henan University of Science and Technology (no. 201706001). All of the animal experiments were performed in our laboratory.

The bacterial strains and plasmids used in this study are listed in Table 2. Liquid bacterial cultures were maintained in LB broth. The J774A.1 Macrophage cell line (Resource Center, IBMS, CAMS/PUMC 3111C0001CCC000222) was obtained from the American Type Culture Collection (ATCC, Manassas, VA). The cells were grown and maintained in Dulbecco's Modified Eagle Medium (Sigma, China) supplemented with $10 \%$ fetal bovine serum (FBS) (Gibco, China) at $37^{\circ} \mathrm{C}$ with $5 \% \mathrm{CO}_{2}$.

\section{Construction of the $\Delta s s e K 2$ mutant and its complemented strain}

The $\Delta$ sseK2 mutant was constructed using methods described previously $[40,41]$. The primers are shown in Table 3. The sseK2 gene was amplified by PCR, and the recombinant plasmid pBSK-sseK2 containing the sseK2 gene was constructed. The sseK2 gene was deleted inframe, and then the recombinant plasmid pRE112 $\Delta s e K 2$ was constructed and transformed into E. colix7213 ( $\lambda$ pir) for mobilization into the WT by conjugation. Singlecrossover transconjugants (in which the recombinant plasmid pRE112 $\triangle$ sseK2 was integrated into the chromosome) were identified and screened on LB plates containing chloramphenicol. Ten percent sucrose was added to $\mathrm{LB}$ plate without $\mathrm{NaCl}$ and with chloramphenicol and the pRE112 suicide plasmid removed from the singlecrossover transconjugants. Chloramphenicol-sensitive colonies were selected, and the $s s e K 2$ deletion was screened for by PCR using primers sseK2-F and sseK2-R. Subsequently, DNA sequencing was performed to confirm whether sseK2 was deleted. The sseK2 gene was cloned into the pBR322 plasmid for complementation studies.

\section{Growth and phenotypic characterization assay}

Growth and phenotypic characterization was performed as previously described [42]. Three colonies were picked and inoculated into $10 \mathrm{ml}$ of fresh LB broth, then 
Table 2 Bacterial strains and plasmids used in this study

\begin{tabular}{|c|c|c|}
\hline Strain or plasmid & Characteristics & Source or reference \\
\hline \multicolumn{3}{|l|}{ Strains } \\
\hline SL1344 & Serovar Typhimurium, wild-type & {$[38]$} \\
\hline SL1344AsseK2 & ssek2 deletion mutant & In this study \\
\hline$x 7213$ & $x 7213$, containing plasmid of pREssek2, $\mathrm{Cm}^{r}$ & In this study \\
\hline Plasmids & & Laboratory stock \\
\hline pBluescriptllSK (+) & Phagemid cloning vector, oriCOLE1 oriF1(+) bla lacZa & In this study \\
\hline pBSKssek2 & pBluescriptllKSt, sseK2 & [39] \\
\hline pRE112 & pGP704 suicide plasmid, pir dependent, oriT, oriV, sacB, $\mathrm{Cm}^{r}$ & In this study \\
\hline pRE $\Delta s s e K 2$ & pRE112 dervative containing ssek2 fused in-frame, $\mathrm{Cm}^{\mathrm{r}}$ & Laboratory stock \\
\hline pBR322 & oriColE1, Amp'Tc ${ }^{r}$ & In this study \\
\hline pBR322-ssek2 & pBR322 carrying the full ssek2gene (Amp') & \\
\hline
\end{tabular}

incubated overnight at $37^{\circ} \mathrm{C}$. The overnight culture was diluted 1:100 into fresh LB broth and incubated overnight at $37{ }^{\circ} \mathrm{C}$ with shaking. The overnight cultures were then, serially diluted and plated to LB medium for plate counts. The index generation time was calculated based on the growth rate from 1 to $14 \mathrm{~h}$.

\section{Stability of the $\Delta$ sseK2 mutant}

To determine the stability of the $\Delta s s e K 2$ cassette postchromosomal integration, a liquid culture of the $\Delta s s e K 2$ strain ( $1 \%$ inoculum) was serially passaged 60 times every $12 \mathrm{~h}$. Every 10 passages, DNA extraction for detection of $\Delta s s e K 2$ by PCR.

\section{Biofilm formation and morphotype assay}

The biofilm formation and morphotype assay was performed as previously described [43]. Briefly, suspension of the WT, $\Delta s s e K 2$, and complemented strains were adjusted to the same concentration, and at $28^{\circ} \mathrm{C}$ for $72 \mathrm{~h}$ in a 96-well cell culture plate without shaking in a humidified environment. Each well of the 96-well plate was slowly washed three times with PBS (phosphate buffered saline) ( $\mathrm{pH}$ 7.0), and then allowed to dry at $37^{\circ} \mathrm{C}$ for 30 $\mathrm{min}$. Then, $100 \mu \mathrm{l}$ of crystal violet $(10 \mathrm{mg} / \mathrm{ml}$; Sigma $)$ was added to each well of the 96-well plate for $30 \mathrm{~min}$.
Subsequently, $100 \mu \mathrm{l}$ of absolute ethanol was added to each well, and biofilm formation was measured by determining the OD (optical density) at $570 \mathrm{~nm}$.

\section{Adherence and invasion assays}

Approximately $1 \times 10^{5} \mathrm{~J} 774 \mathrm{~A} .1$ cells were added to each well of a 24-well plate. The WT, $\Delta s s e K 2$ and complementary strains were then added to the J774A.1 cells at a multiplicity of infection (MOI) of 100:1. After incubation for $2 \mathrm{~h}$ at $37^{\circ} \mathrm{C}$, each well was washed three times with PBS. The wells were then treated with $0.25 \%$ trypsin, serially diluted, and plated, and colony counts were performed to determine the number of adhesive cells. For the invasion assay, $100 \mu \mathrm{g} / \mathrm{ml}$ gentamicin was added to each well for $1 \mathrm{~h}$ at $37^{\circ} \mathrm{C}$, and the cells were then lysed with $0.1 \%$ Triton X-100. To calculated the invasion rate, serially diluted cell lysates were evenly plated onto SS (Salmonella Shigella) agar, and the number of CFUs was determined. The data shown are representative of at least three independent experiments for each strain, which were performed in triplicate.

\section{Intracellular proliferation assay}

Approximately $1 \times 10^{5}$ J774A. 1 murine macrophage cells were added to each well of 6-well plates. Subsequently,

Table 3 Sequences of the primers used in this study

\begin{tabular}{|c|c|c|}
\hline Primer & Primer sequences & Restriction site \\
\hline$\Delta$ ssek2-up-F & 5'-TCTAGAATAGAAGAGGCCCAAAGA-3' & $X b a 1$ \\
\hline$\Delta s s e k 2-u p-R$ & 5'-GGATCCATTITTACACGCTTAAATTA-3' & BamH I \\
\hline$\Delta$ ssek2-down-F & 5'-CTCGAG TCATGATAGCCTTGTTITAC -3' & Xho I \\
\hline$\Delta$ ssek2-down-R & 5'-GGTACC ACACGGCGCACTATTAGA-3' & Kpn I \\
\hline ssek2- F & 5'-ACCACACTAACCAAAGCGCA-3' & \\
\hline $\operatorname{ssek} 2-R$ & 5'-GCAGAGAATAATGGACCACAT-3' & \\
\hline pBR -ssek2-F & 5'-GGATCCATGGCACGTTITAATGCC-3' & BamHI \\
\hline pBR -ssek2-R & 5'-CTCGACTTACCTCCAAGAACTGGCAG-3' & Sall \\
\hline
\end{tabular}


the cells were infected and the invasion assay was performed as previously described. After incubating for 30 min, the cells were washed three times, $150 \mu \mathrm{l}$ of fresh medium containing gentamicin $(50 \mu \mathrm{g} / \mathrm{ml})$ was added to the wells. Two hours later, the infected cells were lysed with $1 \mathrm{ml} 0.1 \%$ Triton X-100 for $10 \mathrm{~min}$. The number of CFUs was determined by plating the cell lysates on SS agar.

\section{$\mathrm{LD}_{50}$ and persistence assay}

Ninety-six (SPF) BALB/c mice were divided randomly into five subgroups, each of which contained three male mice and three female mice. Based on the results from the preliminary study, mice in the $\Delta s s e K 2$ mutant group were inoculated orally with $0.2 \mathrm{ml}$ of liquid culture containing of $4.8 \times 10^{9}, 1.2 \times 10^{9}, 2.4 \times 10^{8}, 2.4 \times 10^{7}$ or $2.4 \times$ $10^{6} \mathrm{CFU}$, the mice in the WT group received $2.25 \times 10^{8}$, $2.25 \times 10^{7}, 2.25 \times 10^{6}, 2.25 \times 10^{5}$, or $2.25 \times 10^{4} \mathrm{CFU}$, and the mice in the complemented group received $2.2 \times 10^{8}$, $2.2 \times 10^{7}, 2.2 \times 10^{6}, 1.1 \times 10^{5}$, or $1.1 \times 10^{4} \mathrm{CFU}$. Six of the mice were inoculated orally with $0.2 \mathrm{ml}$ PBS as a negative control. The $\mathrm{LD}_{50}$ at 35 days post infection was calculated using the previously established Bliss method [44].

Based on the $\mathrm{LD}_{50}$ result, 32 mice were randomized to four groups, each group of 4 groups, each of which contained four male mice and four female mice. On days 0 and 14, 16 mice were vaccinated with the $0.2 \mathrm{ml}$ of liquid culture containing $1 \times 10^{7} \mathrm{CFU}$ of $\triangle \mathrm{sseK} 2$ mutant, seven days later, eight mice were orally inoculated with $0.2 \mathrm{ml}$ of liquid culture containing $1 \times 10^{7}$ CFU (lethal dose) of the WT and eight mice received $0.2 \mathrm{ml}$ PBS. At the same time, 16 mice were orally inoculated with $0.2 \mathrm{ml} \mathrm{PBS}$; seven days later, eight of these mice received $0.2 \mathrm{ml}$ of liquid culture containing $1 \times$ $10^{7} \mathrm{CFU}$ (lethal dose) of the WT strain, and eight received $0.2 \mathrm{ml}$ PBS.

\section{Bacterial load analysis}

Forty-eight mice were divided randomly into three groups, each of which contained 15 mice. Three of the mice received an intraperitoneal injection of $0.2 \mathrm{ml}$ PBS as a negative control. The other mice were infected with $1 \times 10^{5} \mathrm{CFU}$ of the different strains by intraperitoneal injection and were then killed at different time points ( $4 \mathrm{~h}, 24 \mathrm{~h}, 48 \mathrm{~h}, 72 \mathrm{~h}$ and $120 \mathrm{~h}$ ). The spleen, liver, and PPs were collected from each mouse and homogenized in PBS. All samples were then serially diluted and evenly spread onto SS agar. The number of CFUs for each sample was determined $24 \mathrm{~h}$ later. For this animal experiment, the mice were anaesthetized with a $20 \%$ urethane (ethyl carbamate) solution. All animals were humanely handled.

\section{Statistical analysis}

The data are showed as mean \pm standard deviation (SD) and are representative of three independent experiments. One-way ANOVA was employed to identify the significant differences between the groups using the GraphPad Prism software version 5.0. A value of $P<0.05$ was considered significant.

\section{Additional file}

Additional file 1: ARRIVE guidelines. (PDF $191 \mathrm{~kb}$ )

\section{Abbreviations}

Cmr: Chloramphenicol; PCR: Polymerase chain reaction; SD: Standard deviation

\section{Acknowledgments}

The authors sincerely thank Dr. Lei He, Chunjie Zhang, Xiangzhao Cheng and Yinju Li for their support and for critically reviewing this manuscript. We thank Roy Curtiss III for providing strains and plasmids. We thank Liwen Bianji, Edanz Group China (www.liwenbianji.cn/ac), for editing the English text of a draft of this manuscript.

\section{Authors' contributions}

$\mathrm{XZ}$ and LH performed the experiments, analyzed the experimental results and wrote manuscript. $C Z, X Z$, and $L H$ conceived of and designed the experiments. $C Y, Y Y, Y J$, and $X Z$ analyzed experiment performance. $X C, Y L$, $C L$, and $Y J$ analyzed and interpreted all of the data. $J L, Z Y$, and FD performed the statistical analyse. $C Z, X C$, and $Y L$ did the supervised study. All authors read and approved the manuscript.

\section{Funding}

This study was funded by the Natural Science Foundation of Henan Province China (Grant 182300410078) and the National Natural Science Foundation of China (Grant 31572489). The funding entities had no role in design of the study, collection, analysis or interpretation of data, or writing of the manuscript.

\section{Availability of data and materials}

The data generated and/or analyzed during the current study are available from the corresponding author on reasonable request.

\section{Ethics approval}

All animals experiment protocols were reviewed and approved by the Institutional Animal Care and Use Committee (IACUC) of the College of Animal Science and Technology, Henan University of Science and Technology (no. 201706001). All animals were humanely handled.

\section{Consent for publication}

Not applicable.

\section{Competing interests}

The authors declare that they have no competing of interests.

\section{Author details}

${ }^{1}$ The Key Lab of Animal Disease and Public Health, Henan University of Science and Technology, 263 Kaiyuan Avenue, Luoyang 471023, Henan, China. 'Luoyang Key Laboratory of Live Carrier Biomaterial and Animal Disease Prevention and Control, Luoyang 471023, Henan, China. ${ }^{3}$ Luoyang Polytechnic, 6 Airport Road, Luoyang 471023, Henan, China.

Received: 11 December 2018 Accepted: 18 July 2019

Published online: 07 August 2019

\section{References}

1. Waterman SR, Holden DW. Functions and effectors of the Salmonella pathogenicity island 2 type III secretion system. Cell Microbiol. 2003;5(8): 501-11. 
2. Majowicz SE, Musto J, Scallan E, Angulo FJ, Kirk M, O'Brien SJ, Jones TF, Fazil A, Hoekstra RM. International collaboration on enteric disease 'Burden of illness S: the global burden of nontyphoidal Salmonella gastroenteritis. Clin Infect Dis. 2010;50(6):882-9.

3. Chaudhuri D, Roy Chowdhury A, Biswas B, Chakravortty D. Salmonella typhimurium infection leads to colonization of the mouse brain and is not completely cured with antibiotics. Front Microbiol. 2018;9:1632.

4. Yu XJ, Grabe GJ, Liu M, Mota LJ, Holden DW. SsaV Interacts with SsaL to Control the Translocon-to-Effector Switch in the Salmonella SPI-2 Type Three Secretion System. MBio. 2018:9(5).

5. Chen S, Zhang C, Liao C, Li J, Yu C, Cheng X, Yu Z, Zhang M, Wang Y. Deletion of invasion protein $B$ in Salmonella enterica Serovar typhimurium influences bacterial invasion and virulence. Curr Microbiol. 2015;71(6):687-92.

6. Miao EA, Warren SE. Innate immune detection of bacterial virulence factors via the NLRC4 inflammasome. J Clin Immunol. 2010;30(4):502-6.

7. Hu M, Zhao W, Gao W, Li W, Meng C, Yan Q, Wang Y, Zhou X, Geng S, Pan $Z$, et al. Recombinant Salmonella expressing SspH2-Escl fusion protein limits its colonization in mice. BMC Immunol. 2017;18(1):21.

8. Lawley TD, Chan K, Thompson L, Kim CC, Govoni GR, Monack DM. Genome-wide screen for Salmonella genes required for long-term systemic infection of the mouse. PLoS Pathog. 2006;2(2):e11.

9. Brown NF, Coombes BK, Bishop JL, Wickham ME, Lowden MJ, Gal-Mor O, Goode DL, Boyle EC, Sanderson KL, Finlay BB. Salmonella phage ST64B encodes a member of the SseK/NleB effector family. PLoS One. 2011;6(3):e17824.

10. Kujat Choy SL, Boyle EC, Gal-Mor O, Goode DL, Valdez Y, Vallance BA, Finlay BB. SseK1 and SseK2 are novel translocated proteins of Salmonella enterica serovar typhimurium. Infect Immun. 2004;72(9):5115-25.

11. Gunster RA, Matthews SA, Holden DW, Thurston TL. SseK1 and SseK3 Type III Secretion System Effectors Inhibit NF-kappaB Signaling and Necroptotic Cell Death in Salmonella-Infected Macrophages. Infect Immun. 2017:85(3).

12. Esposito D, Gunster RA, Martino L, El Omari K, Wagner A, Thurston TLM, Rittinger K. Structural basis for the glycosyltransferase activity of the Salmonella effector SseK3. J Biol Chem. 2018;293(14):5064-78.

13. Park JB, Kim YH, Yoo Y, Kim J, Jun SH, Cho JW, El Qaidi S, Walpole S, Monaco S, Garcia-Garcia AA, et al. Structural basis for arginine glycosylation of host substrates by bacterial effector proteins. Nat Commun. 2018;9(1):4283.

14. Yang Y, Yu C, Ding K, Zhang C, Liao C, Jia Y, Li J, Cheng X. Role of the sseK1 gene in the pathogenicity of Salmonella enterica serovar enteritidis in vitro and in vivo. Microb Pathog. 2018;117:270-5.

15. El Qaidi S, Zhu C, McDonald P, Roy A, Maity PK, Rane D, Perera C, Hardwidge PR. High-throughput screening for bacterial glycosyltransferase inhibitors. Front Cell Infect Microbiol. 2018;8:435

16. Mastroeni P, Chabalgoity JA, Dunstan SJ, Maskell DJ, Dougan G. Salmonella: immune responses and vaccines. Vet J. 2001;161(2):132-64.

17. Clark-Curtiss JE, Curtiss R 3rd. Salmonella vaccines: conduits for protective antigens. J Immunol. 2018;200(1):39-48.

18. Donlan RM, Costerton JW. Biofilms: survival mechanisms of clinically relevant microorganisms. Clin Microbiol Rev. 2002;15(2):167-93.

19. Wang $Y$, Wang $Y$, Sun L, Grenier D, Yi L. Streptococcus suis biofilm: regulation, drug-resistance mechanisms, and disinfection strategies. Appl Microbiol Biotechnol. 2018;102(21):9121-9.

20. Wakimoto N, Nishi J, Sheikh J, Nataro JP, Sarantuya J, Iwashita M, Manago K, Tokuda K, Yoshinaga M, Kawano Y. Quantitative biofilm assay using a microtiter plate to screen for enteroaggregative Escherichia coli. Am J Trop Med Hyg. 2004;71(5):687-90.

21. Joseph B, Otta SK, Karunasagar I, Karunasagar I. Biofilm formation by salmonella spp. on food contact surfaces and their sensitivity to sanitizers. Int J Food Microbiol. 2001;64(3):367-72

22. Marin C, Hernandiz A, Lainez M. Biofilm development capacity of Salmonella strains isolated in poultry risk factors and their resistance against disinfectants. Poult Sci. 2009:88(2):424-31.

23. Gonzalez-Escobedo G, Marshall JM, Gunn JS. Chronic and acute infection of the gall bladder by Salmonella Typhi: understanding the carrier state. Nat Rev Microbiol. 2011;9(1):9-14

24. Gonzalez-Escobedo G, Gunn JS. Identification of Salmonella enterica serovar typhimurium genes regulated during biofilm formation on cholesterol gallstone surfaces. Infect Immun. 2013;81(10):3770-80.

25. Dong H, Peng D, Jiao X, Zhang X, Geng S, Liu X. Roles of the spiA gene from Salmonella enteritidis in biofilm formation and virulence. Microbiology. 2011;157(Pt 6):1798-805
26. Guard J, Morales CA, Fedorka-Cray P, Gast RK. Single nucleotide polymorphisms that differentiate two subpopulations of Salmonella enteritidis within phage type. BMC Res Notes. 2011;4:369.

27. Martins M, McCusker MP, McCabe EM, O'Leary D, Duffy G, Fanning S. Evidence of metabolic switching and implications for food safety from the phenome(s) of Salmonella enterica serovar typhimurium DT104 cultured at selected points across the pork production food chain. Appl Environ Microbiol. 2013;79(18):5437-49.

28. Leite B, Werle CH, Carmo CPD, Nobrega DB, Milanez GP, Culler HF, Sircili MP, Alvarez-Martinez CE, Brocchi M. Integration host factor is important for biofilm formation by Salmonella enterica Enteritidis. Pathog Dis. 2017:75(6).

29. Bonafonte MA, Solano C, Sesma B, Alvarez M, Montuenga L, Garcia-Ros D, Gamazo C. The relationship between glycogen synthesis, biofilm formation and virulence in salmonella enteritidis. FEMS Microbiol Lett. 2000;191(1):31-6.

30. Van Nhieu GT, Romero S. Common themes in cytoskeletal remodeling by intracellular bacterial effectors. Handb Exp Pharmacol. 2017;235:207-35.

31. Azriel S, Goren A, Rahav G, Gal-Mor O. The stringent response regulator DksA is required for Salmonella enterica Serovar typhimurium growth in minimal medium, motility, biofilm formation, and intestinal colonization. Infect Immun. 2016;84(1):375-84.

32. Haraga A, Ohlson MB, Miller SI. Salmonellae interplay with host cells. Nat Rev Microbiol. 2008:6(1):53-66.

33. Fuche FJ, Jones JA, Ramachandran G, Higginson EE, Simon R, Tennant SM Deletions in guaBA and htrA but not clpX or rfaL constitute a liveattenuated vaccine strain of Salmonella Newport to protect against serogroup C2-C3 Salmonella in mice. Hum Vaccin Immunother. 2018:1-9.

34. Herrero-Fresno A, Espinel IC, Spiegelhauer MR, Guerra PR, Andersen KW, Olsen JE. The Homolog of the Gene bstA of the BTP1 Phage from Salmonella enterica Serovar Typhimurium ST313 Is an Antivirulence Gene in Salmonella enterica Serovar Dublin. Infect Immun. 2018:86(1).

35. Kato J, Dey S, Soto JE, Butan C, Wilkinson MC, De Guzman RN, Galan JE. A protein secreted by the Salmonella type III secretion system controls needle filament assembly. Elife. 2018;7.

36. Dumpa N, Goel K, Guo Y, McFall H, Pillai AR, Shukla A, Repka MA, Murthy SN. Stability of vaccines. AAPS PharmSciTech. 2019;20(2):42.

37. Song BF, Ju LZ, Li YJ, Tang LJ. Chromosomal insertions in the Lactobacillus casei upp gene that are useful for vaccine expression. Appl Environ Microbiol. 2014;80(11):3321-6.

38. Hoiseth SK, Stocker BA. Aromatic-dependent Salmonella typhimurium are non-virulent and effective as live vaccines. Nature. 1981;291(5812):238-9.

39. Edwards RA, Keller LH, Schifferli DM. Improved allelic exchange vectors and their use to analyze 987P fimbria gene expression. Gene. 1998;207(2):149-57.

40. Kang HY, Dozois CM, Tinge SA, Lee TH, Curtiss R 3rd. Transduction-mediated transfer of unmarked deletion and point mutations through use of counterselectable suicide vectors. J Bacteriol. 2002;184(1):307-12.

41. Zhu C, Meng X, Duan X, Tao Z, Gong J, Hou H, Zhu G. SEF14 fimbriae from Salmonella enteritidis play a role in pathogenitic to cell model in vitro and host in vivo. Microb Pathog. 2013;64:18-22.

42. Shippy DC, Eakley NM, Mikheil DM, Fadl AA. Role of the flagellar basal-body protein, FlgC, in the binding of Salmonella enterica serovar Enteritidis to host cells. Curr Microbiol. 2014;68(5):621-8.

43. Stepanovic S, Vukovic D, Hola V, Di Bonaventura G, Djukic S, Cirkovic I, Ruzicka F. Quantification of biofilm in microtiter plates: overview of testing conditions and practical recommendations for assessment of biofilm production by staphylococci. APMIS. 2007;115(8):891-9.

44. Adamson $\mathrm{RH}$. The acute lethal dose 50 (LD50) of caffeine in albino rats. Regul Toxicol Pharmacol. 2016;80:274-6.

\section{Publisher's Note}

Springer Nature remains neutral with regard to jurisdictional claims in published maps and institutional affiliations. 